\title{
A 1-Hydroxy-2,4-Diformylnaphthalene-Based Fluorescent Probe and Its Detection of Sulfites/Bisulfite
}

\author{
Qing Shi ${ }^{1}$, Ling-Yi Shen ${ }^{2}$, Hong $X u^{1,2}$, Zhi-Yong Wang ${ }^{2}$, Xian-Jiong Yang ${ }^{2}$, Ya-Li Huang ${ }^{2, *}$, Carl Redshaw $^{3} \mathbb{D}$ \\ and Qi-Long Zhang 1,2,*
}

1 The Key Laboratory of Environmental Pollution Monitoring and Disease Control, School of Public Health, Ministry of Education, Guizhou Medical University, Guiyang 550004, China; shiqing5900@126.com (Q.S.); xuhong@gmc.edu.cn (H.X.)

2 School of Basic Medical Science, Guizhou Medical University, Guiyang 550004, China; shenly@stumail.nwu.edu.cn (L.-Y.S.); zq1810921@163.com (Z.-Y.W.); yangxianjiong@126.com (X.-J.Y.)

3 Department of Chemistry, University of Hull, Cottingham Road, Hull HU6 7RX, UK; c.redshaw@hull.ac.uk

* Correspondence: ylh6401@gmc.edu.cn (Y.-L.H.); gzuqlzhang@126.com (Q.-L.Z.); Fax: +86-0851-88174017 (Q.-L.Z.)

Citation: Shi, Q.; Shen, L.-Y.; Xu, H.; Wang, Z.-Y.; Yang, X.-J.; Huang, Y.-L.; Redshaw, C.; Zhang, Q.-L. A

1-Hydroxy-2,4-DiformylnaphthaleneBased Fluorescent Probe and Its Detection of Sulfites/Bisulfite. Molecules 2021, 26, 3064. https:// doi.org/10.3390/molecules26113064

Academic Editor: Ugo Caruso

Received: 8 April 2021

Accepted: 12 May 2021

Published: 21 May 2021

Publisher's Note: MDPI stays neutral with regard to jurisdictional claims in published maps and institutional affiliations.

Copyright: (c) 2021 by the authors. Licensee MDPI, Basel, Switzerland. This article is an open access article distributed under the terms and conditions of the Creative Commons Attribution (CC BY) license (https:// creativecommons.org/licenses/by/ $4.0 /)$.

\begin{abstract}
A novel 1-hydroxy-2,4-diformylnaphthalene-based fluorescent probe $\mathbf{L}$ was synthesized by a Knoevenagel reaction and exhibited excellent sensitivity and selectivity towards sulfite ions $\left(\mathrm{SO}_{3}{ }^{2-}\right)$ and bisulfite ions $\left(\mathrm{HSO}_{3}{ }^{-}\right)$. The detection limits of the probe $\mathbf{L}$ were $0.24 \mu \mathrm{M}$ using $\mathrm{UV}$-Vis spectroscopy and $9.93 \mathrm{nM}$ using fluorescence spectroscopy, respectively. Furthermore, the fluorescent probe $\mathbf{L}$ could be utilized for detection in real water samples with satisfactory recoveries in the range $99.20 \% \sim 104.30 \%$ in lake water and $100.00 \% \sim 104.80 \%$ in tap water by UV-Vis absorption spectrometry, and in the range $100.50 \% \sim 108.60 \%$ in lake water and $102.70 \% \sim 103.80 \%$ in tap water by fluorescence spectrophotometry.
\end{abstract}

Keywords: fluorescent probe; sulfite/bisulfite; crystal structure; real sample detection

\section{Introduction}

Levels of anions including organic and inorganic anions (such as sulfurous acid root, amino acids, etc.) are of interest to the field of food analysis, yet they widely exist in food, and also can be used as food additives by being externally added to the food. Moreover, during the food production process, contamination can accidentally arise during one or even several stages, which could result in excessive amounts of anions in the food. These anions not only affect the color, aroma, taste and other qualities of food, but can also play an important role in the health effect of food. In order to evaluate food quality and safety quickly and accurately, it is necessary to carry out qualitative and quantitative analysis of anions with the help of effective analytical testing methods. This is required in order to provide a scientific basis for food production technology, food storage management and monitoring, as well as adherence to the corresponding rules and regulations [1].

Among the differing kinds of anions, sulfite/bisulfite anions $\left(\mathrm{SO}_{3}{ }^{2-} / \mathrm{HSO}_{3}{ }^{-}\right)$plays a crucial role in food preservation due to their characteristics of anti-oxidation, anticorrosion and enzyme inhibitor, and so are often widely used as food additives in the food industry [2,3]. One of the main atmospheric pollutants is sulfur dioxide $\left(\mathrm{SO}_{2}\right)$ in the physiological environment, and this results in sulfite in treatments with an aqueous base. Large doses of sulfite are toxic to humans and animals and can readily cause adverse reactions and diseases, allergies and severe skin irritation, as well as respiratory problems such as asthma, coughing and gastrointestinal disorders [4-7]. Other issues include diarrhea, headaches, hypotension, lung cancer and a variety of nervous system diseases [8]. Thus, the amount of sulfite in many countries is strictly controlled and standards are set by the likes of the Food and Agriculture Organization (FAO)/World Health Organization (WHO). JECFA announced that the acceptable daily intake should be less than $0.70 \mathrm{mg} / \mathrm{kg}$ [3], 
and therefore a method for the rapid and sensitive detection of $\mathrm{SO}_{3}{ }^{2-} / \mathrm{HSO}_{3}{ }^{-}$in solution would be highly desirable for environmental monitoring, and would also have practical value in the detection of biomedical food safety $[9,10]$. At present, methods for the detection of $\mathrm{SO}_{3}{ }^{2-} / \mathrm{HSO}_{3}{ }^{-}$mainly include ion chromatography/electrochemical methods such as capillary electrophoresis fluorescence [2,11]. According to the Chinese "Standards for the Use of Food Additives" GB/T5009.34-2003 "Determination of Sulfites in Food" colorimetric method, sulfur dioxide in food after extraction should be reacted with detection reagents to generate colored compounds, with a detector at $550 \mathrm{~nm}$ for the determination of its absorbance, and a certain range of absorbance is proportional to its content. The detection limit was $4.18 \mu \mathrm{M}$. When compared with the traditional method of measuring the sulfite, the fluorescent probe detection method has great potential because of its high sensitivity, high selectivity, non-destructive detection and in situ visualized detection [12-16]. In recent years, the fields of medical biochemistry analysis and environmental monitoring have received widespread attention [17], with water, food and biological systems being subject to study with powerful visual detection tools for anions [18-21].

In this research, we develop a fluorescent probe $\mathbf{L}$ which exhibits a good recognition performance and anti-interference ability. It can detect $\mathrm{SO}_{3}{ }^{2-} / \mathrm{HSO}_{3}{ }^{-}$in a water environment using UV-Vis absorption spectroscopy and fluorescence spectroscopy.

\section{Materials and Methods}

\subsection{Equipment and Reagents}

The equipment we used included: an Inova- $400 \mathrm{MHz}$ NMR Spectrometer (Varian Company, Palo Alto, CA, USA); a VGT-2227QTD type ultrasonic instrument (Shenzhen Gute Hongye Machinery Equipment Co., Ltd., Shenzhen, China); a CP214 Electronic Balance (Shanghai Aohaus Instrument Co., Ltd., Shanghai, China); a Cary Eclipse type fluorescence spectrophotometer (Varian Company, Palo Alto, CA, USA); a UV-visible spectrophotometer of UV-2600 (Suzhou Dao Jin Instrument Co., Ltd., Suzhou, China); a pH meter of pHS-25 (Chengdu Century Ark Technology Co., Ltd., Chengdu, China); and a Bruker Smart Apex single crystal diffractometer (Bruker AXS Company, Karlsruhe, Germany).

1,3,3-Trimethyl-2-methyliminoline, 1-naphthol, hexamethylenetetramine, trifluoroacetic acid, ethyl acetate, methanol, ethanol (EtOH), hexane, dimethyl sulfoxide (DMSO), hydrochloric acid $(\mathrm{HCl})$, anionic metal ions and amino-containing small molecules such as cysteine (Cys) are commercially available and were purchased from Aladdin reagent co., LTD. (Shanghai, China). All chemicals were of analytical grade and were used without further purification. Ultrapure water of $18.2 \mathrm{M} \Omega \mathrm{cm}$ resistivity was obtained through a water purification system (Youpu Super Pure Technology Co., Ltd. Sichuan, China) and was used in all experiments.

\subsection{Synthesis of the Compound 1a}

One gram $(6.90 \mathrm{mmol})$ of 1-naphthol and $1.94 \mathrm{~g}(13.80 \mathrm{mmol})$ of hexamethylenetetramine were dissolved in $10 \mathrm{~mL}$ trifluoroacetic acid and stirred at $85^{\circ} \mathrm{C}$ for $1 \mathrm{~h}$. After cooling, $10 \mathrm{~mL}$ of concentrated sulfuric acid diluted to $33 \%$ concentration was slowly added into the mixture, and reflux was continued for $1 \mathrm{~h}$. Then, the mixture was twice extracted with ethyl acetate, washed with brine and then dried with anhydrous magnesium sulfate. Filtration, followed by column chromatography separation ( $n$-hexane/ ethyl acetate $=7: 3$, $v / v$ as eluent), afforded a yellow solid $(2.09 \mathrm{~g})$ with a yield of $71 \%$, and the molecular formula of compound $1 \mathrm{a}$ is $\mathrm{C}_{12} \mathrm{H}_{8} \mathrm{O}_{3}$.

\subsection{Synthesis of the Fluorescent Probe $\mathbf{L}$}

In this process, $0.20 \mathrm{~g}(1 \mathrm{mmol})$ of compound $1 \mathrm{a}$ and $0.17 \mathrm{~g}(1 \mathrm{mmol})$ of 1,3,3-trimethyl2-methylene indoline were mixed in $40 \mathrm{~mL}$ anhydrous ethanol and stirred at $85^{\circ} \mathrm{C}$ for $8 \mathrm{~h}$, and then concentrated under reduced pressure, and separated using column chromatography ( $n$-hexane/ethyl acetate $=7: 3, v / v$ as eluent) to obtain a bright green powder $(0.18 \mathrm{~g})$ in $50 \%$ yield. The molecular formula of the fluorescent probe $\mathbf{L}$ is $\mathrm{C}_{24} \mathrm{H}_{23} \mathrm{NO}_{2} .{ }^{1} \mathrm{H}$ NMR (600 MHz, CD 3 OD): $\delta 10.21(\mathrm{~s}, 1 \mathrm{H}), 10.04(\mathrm{~s}, 1 \mathrm{H}), 9.20-9.22(\mathrm{~d}, J=12 \mathrm{~Hz}, 1 \mathrm{H}), 9.00-9.07$ 
$(\mathrm{d}, J=42 \mathrm{~Hz}, 1 \mathrm{H}), 8.00-8.02(\mathrm{~d}, J=12 \mathrm{~Hz}, 1 \mathrm{H}), 6.92-7.92(\mathrm{~m}, 4 \mathrm{H}), 6.68-6.59(\mathrm{~d}, J=61 \mathrm{H})$, $5.81-5.83(\mathrm{~d}, J=12,1 \mathrm{H}), 5.33(\mathrm{~s}, 1 \mathrm{H}), 3.90(\mathrm{~s}, 1 \mathrm{H}), 2.75(\mathrm{~s}, 3 \mathrm{H}), 1.35(\mathrm{~s}, 3 \mathrm{H}), 1.35(\mathrm{~s}, 3 \mathrm{H})$. ${ }^{13} \mathrm{C}$ NMR $\left(151 \mathrm{MHz} \mathrm{CDCl}_{3}\right) \delta 191.80,191.20,153.40,137.10,131.78,128.89,128.71,127.71$, 126.53, 126.26, 125.42, 125.14, 125.05, 107.16, 107.11, 102.86, 28.94, 28.72, 28.48, 25.90, 20.13. HRMS calculated: 356.1645 , found 356.1650 .

\subsection{X-ray Crystallography}

Crystallographic data for ligand $\mathbf{L}$ were collected on a Bruker APEX 2 CCD diffractometer with graphite-monochromated Mo K $\alpha$ radiation $(\lambda=0.71073 \AA)$ in the $\omega$ scan mode [21]. The structure was solved by a charge flipping algorithm and refined by full-matrix least-squares methods on F2 [22]. All esds were estimated using the full covariance matrix. Further details are presented in Table S1. CCDC: 2059923, L. These data can be obtained free of charge from The Cambridge Crystallographic Data Centre via www.ccdc.cam.ac.uk/data_request/cif (31 January 2021).

\subsection{General Methods for Optical Tests}

In this process, $5.3 \mathrm{mg}(15 \mu \mathrm{M})$ of probe $\mathbf{L}$ was dissolved in $10.00 \mathrm{~mL}$ of EtOH solution to prepare a $1.50 \mathrm{mM}$ stock solution. Then, the nitrates of the metal ions, the sodium salt of anions and small amino molecules $\left(\mathrm{Ag}^{+}, \mathrm{Al}^{3+}, \mathrm{Cd}^{2+}, \mathrm{Co}^{2+}, \mathrm{Cr}^{3+}, \mathrm{Cu}^{2+}, \mathrm{Fe}^{3+}, \mathrm{Hg}^{2+}\right.$, $\mathrm{K}^{+}, \mathrm{Li}^{+}, \mathrm{Mg}^{2+}, \mathrm{Na}^{+}, \mathrm{Ni}^{2+}, \mathrm{Pb}^{2+}, \mathrm{Zn}^{2+}, \mathrm{AcO}^{-}, \mathrm{Br}^{-}, \mathrm{C}_{2} \mathrm{O}_{4}{ }^{2-}, \mathrm{ClO}_{4}{ }^{-}, \mathrm{Cl}^{-}, \mathrm{CN}^{-}, \mathrm{CO}_{3}{ }^{2-}$, $\mathrm{F}^{-}, \mathrm{H}_{2} \mathrm{PO}_{4}{ }^{-}, \mathrm{HCO}_{3}{ }^{-}, \mathrm{HSO}_{3}{ }^{-}, \mathrm{HPO}_{4}{ }^{2-}, \mathrm{I}^{-}, \mathrm{NO}^{2-}, \mathrm{PO}_{4}{ }^{3-}, \mathrm{S}_{2} \mathrm{O}_{3}{ }^{2-}, \mathrm{SO}_{3}{ }^{2-}, \mathrm{SO}_{4}{ }^{2-}, \mathrm{GSH}$, Hcy, $\mathrm{H}_{2} \mathrm{NCONH}_{2}$, Cys) were accurately weighed and dissolved in $10.00 \mathrm{~mL}$ of PBS buffer to form $10 \mathrm{mM}$ ion stock solutions. The preparation method of the PBS buffer solution (10 mM) was as follows: $23 \mathrm{~g}$ of PBS phosphate buffer powder was weighed and dissolved in $2 \mathrm{~L}$ of ultrapure water, and the $\mathrm{pH}$ ranged from 7.20 to 7.40 .

\section{Results and Discussion}

\subsection{Synthesis}

A new fluorescent probe $\mathbf{L}$ was obtained from 1-hydroxy-2,4-diformylnaphthalene (compound 1a, synthesized from 1-naphthol and hexamethylenetetramine) and 1,3,3trimethyl-2-methyleneindoline by means of a Knoevenagel reaction, as shown in Scheme 1. The molecular structure was characterized by ${ }^{1} \mathrm{H}$ NMR spectroscopy, HRMS and single crystal X-ray diffraction. The probe $\mathbf{L}$ exhibited excellent solubility in common organic solvents (such as methanol, ethanol, DMSO, etc.) and possessed good acid- and alkaliresistance over the $\mathrm{pH}$ range 3-11 over $24 \mathrm{~h}$ (Tables $\mathrm{S} 2$ and S3). The thickness of the dish is $1 \mathrm{~cm}$; that is, the thickness of the liquid layer. The concentration of $\mathrm{SO}_{3}{ }^{2-} / \mathrm{HSO}_{3}{ }^{-}$was $0.45 \mu \mathrm{M}$, and $\varepsilon \max =17,608.89 \mathrm{~L} \cdot \mathrm{mol}^{-1} \cdot \mathrm{cm}^{-1}, \lambda(\mathrm{abs})=550 \mathrm{~nm}$. This work provides a new strategy for the practical application of small molecule probes in the field of anion detection.

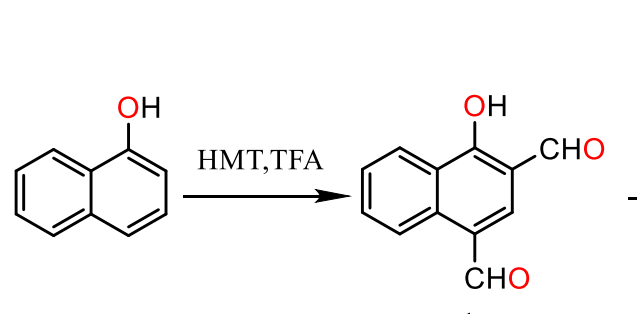

$1 \mathrm{a}$

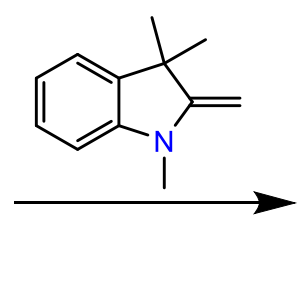

Scheme 1. Synthetic route to probe $\mathbf{L}$.

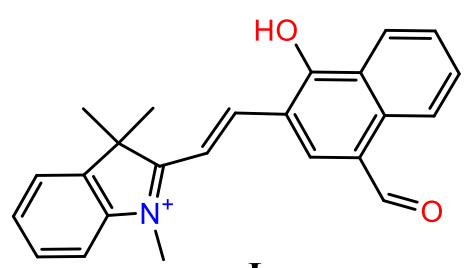

$\mathbf{L}$

\subsection{Determination of Optimum Experimental Conditions}

Anion fluorescent probes are mainly used in the fields of biology, medicine and food monitoring, and so they will have more extensive value if the recognition can be conducted in aqueous solution. In addition, a buffer solution can be used to control the stable $\mathrm{pH}$ value in an aqueous solution, making the results of identification more reliable $[23,24]$. 
Therefore, the influence of water content on probe $\mathbf{L}$ was explored by changing the water content during the experiment.

As shown in Figure 1, the fluorescent probe $\mathbf{L}$ emitted pink emission with $\lambda$ max $\mathrm{em}=605 \mathrm{~nm}$ in pure EtOH solution. As the water fraction $(f \mathrm{w})$ gradually increased from $0 \%$ to $60 \%$, the maximum absorbance and the fluorescence intensity of the probe $\mathbf{L}$ increased with the increase in the water fraction $(f \mathrm{w})$. When the water fraction $(f \mathrm{w})$ reached $60 \%$, the absorbance and the fluorescence intensity of the solution attained the maximum value, and the mixture exhibited bright pink light under $365 \mathrm{~nm}$ UV irradiation. Then, as the water fraction $(f \mathrm{w})$ continued to increase, the fluorescence intensity gradually decreased, and an aggregate-induced quenching process occurred, and the fluorescence quenching efficiency reached $79.95 \%$. Given this, we chose the mixture of $\mathrm{EtOH} /$ water $\left(\mathrm{V}_{\mathrm{EtOH}} / \mathrm{V}_{\mathrm{H} 2 \mathrm{O}}=2: 3\right)$ as the recognition environment.
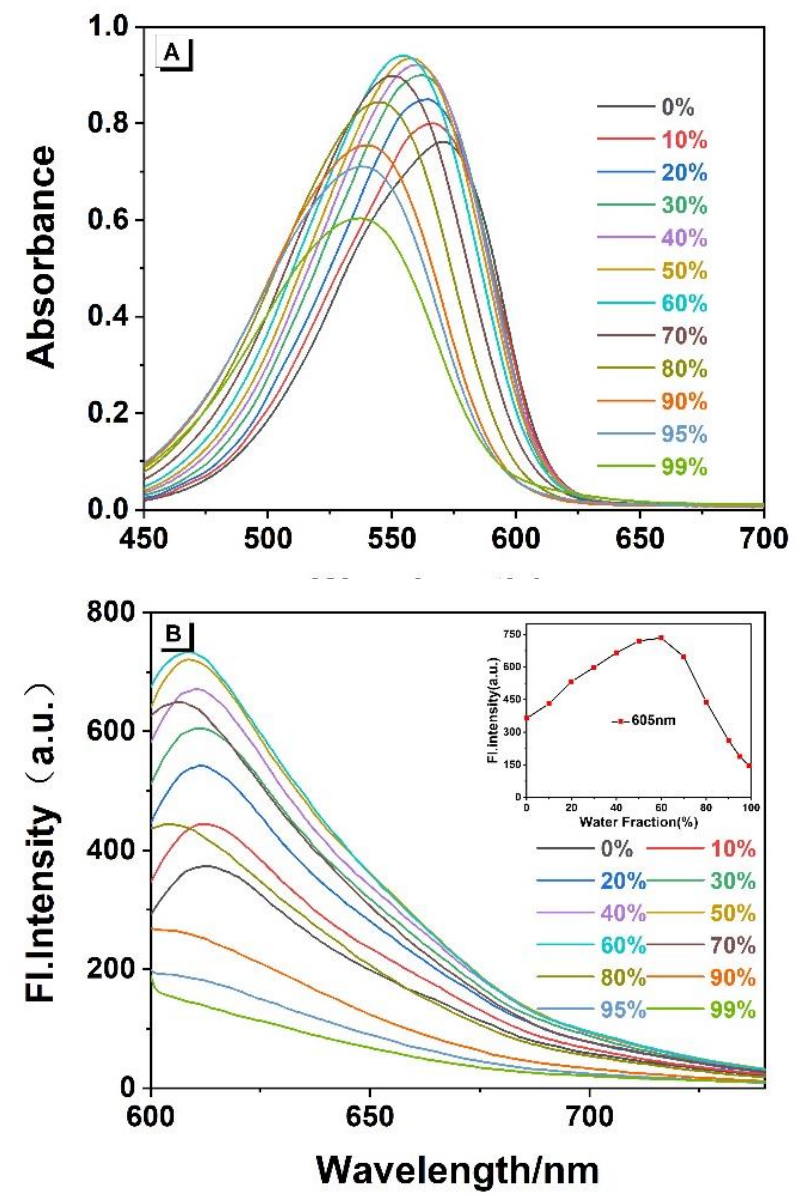

c]

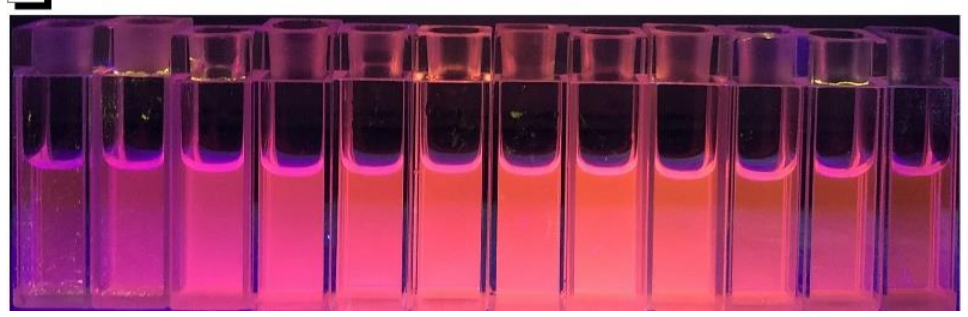

Figure 1. (A) The UV-Vis and (B) fluorescence spectra of the fluorescence probe $\mathbf{L}(15 \mu \mathrm{M})$ in $\mathrm{EtOH} /$ water mixtures with different water fractions $\left(\lambda_{\mathrm{ex}} / \lambda_{\mathrm{em}}=576 \mathrm{~nm} / 605 \mathrm{~nm}\right.$, slit: $5 / 5 \mathrm{~nm}$, voltage: 800 v). (C) Photographs in EtOH/water mixtures with different water fractions taken under $365 \mathrm{~nm}$ UV irradiation. Inset of (B): Plots of fluorescence intensity at $605 \mathrm{~nm}$. 
The $\mathrm{pH}$ value of the environment is a critical parameter that may affect the selectivity, sensitivity and detection limit of the probe [25]. As shown in Figures 2 and 3, the UV-Vis absorption and fluorescence spectra of probe $\mathbf{L}$ and the UV-Vis absorption and fluorescence spectra of sulfites/bisulfites $\left(\mathrm{SO}_{3}{ }^{2-} / \mathrm{HSO}_{3}{ }^{-}\right)$identified by probe $\mathbf{L}$ were experimentally studied over the $\mathrm{pH}$ range of 1 to 14 .
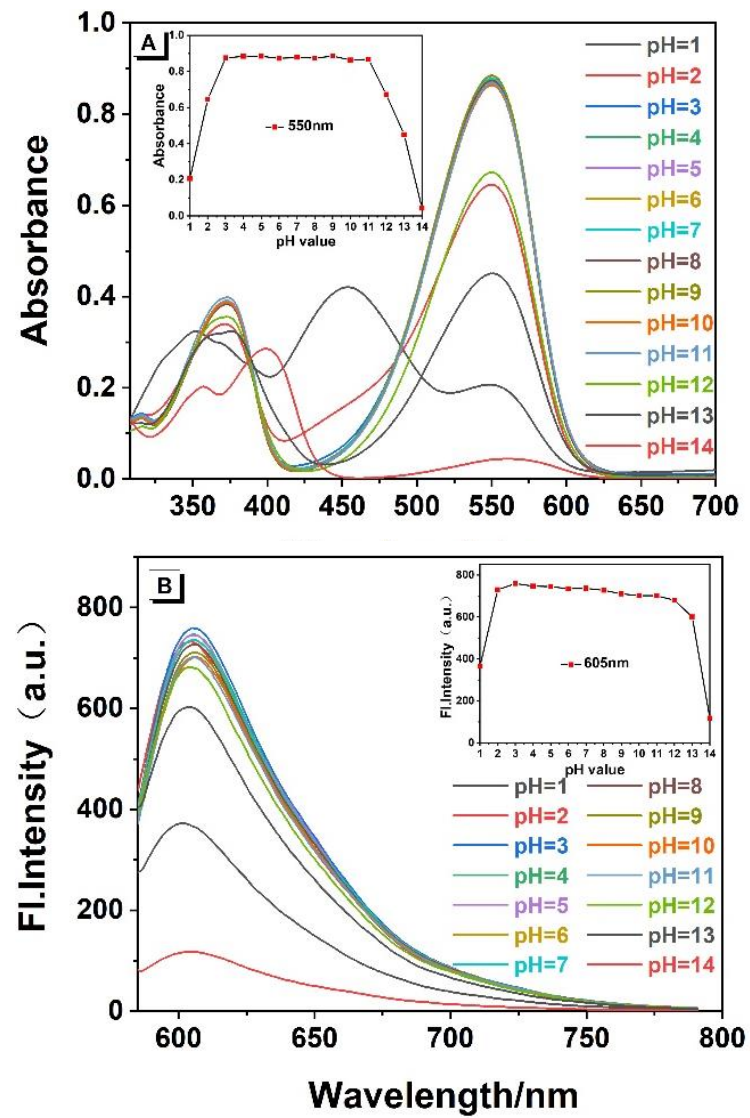

Figure 2. (A) The UV-Vis and (B) Fluorescence spectra of the fluorescence probe $\mathbf{L}(15 \mu \mathrm{M})$ in $\mathrm{EtOH} /$ water $\left(\mathrm{V}_{\mathrm{EtOH}} / \mathrm{V}_{\text {water }}=2 / 3\right)$ at different $\mathrm{pH}$ values $\left(\lambda_{\mathrm{ex}} / \lambda_{\mathrm{em}}=576 \mathrm{~nm} / 605 \mathrm{~nm}\right.$, slit: $5 / 5 \mathrm{~nm}$, voltage: $800 \mathrm{v}$ ). Inset: (A) Effect of different $\mathrm{pH}$ values on the absorbance of probe $\mathbf{L}$ at $550 \mathrm{~nm}$. (B) Influence of $\mathrm{pH}$ values on fluorescence probe $\mathbf{L}$ at $605 \mathrm{~nm}$.

We added $1.80 \mathrm{~mL}$ of PBS buffer solution with different $\mathrm{pH}$ values into a $3.00 \mathrm{~mL}$ colorimetric dish, and then added $0.03 \mathrm{~mL}$ of probe reserve solution. The solution was brought up to a constant volume of $3.00 \mathrm{~mL}$ with anhydrous ethanol, shaken well and left to react completely. The influence of different $\mathrm{pH}$ values on the probe was measured by UV-Vis spectrophotometer and fluorescence photometer. As shown in Figure 2, in the detection system comprised of EtOH/water $\left(\mathrm{V}_{\mathrm{EtOH}} / \mathrm{V}_{\mathrm{H} 2 \mathrm{O}}=2 / 3,10 \mathrm{mM}\right.$ PBS buffer $)$, the maximum absorbance of probe $\mathbf{L}$ is at $550 \mathrm{~nm}$, and the maximum emission peak is at $605 \mathrm{~nm}$ over the $\mathrm{pH}$ range of 3 to 11 . In this wide range, the absorbance and fluorescence intensity of probe $\mathbf{L}$ are only slightly affected by the $\mathrm{pH}$.

We added $1.80 \mathrm{~mL}$ of PBS buffer solution of different $\mathrm{pH}$ into a $3.00 \mathrm{~mL}$ colorimetric dish, then added $22.50 \mu \mathrm{L}$ of $\mathrm{SO}_{3}{ }^{2-} / \mathrm{HSO}_{3}{ }^{-}$reserve solution and $0.03 \mathrm{~mL}$ of probe reserve solution, and used anhydrous ethanol to bring the volume up to $3.00 \mathrm{~mL}$, shook the solution well and left it to stand until the solution was completely reacted. The influence of different $\mathrm{pH}$ on the interaction between probe $\mathrm{L}$ and $\mathrm{SO}_{3}{ }^{2-} / \mathrm{HSO}_{3}{ }^{-}$was determined by $\mathrm{UV}-\mathrm{Vis}$ spectrophotometer and fluorescence photometer. As shown in Figure 3, in the detection system comprising EtOH/water $\left(\mathrm{V}_{\mathrm{EtOH}} / \mathrm{V}_{\mathrm{H} 2 \mathrm{O}}=2 / 3,10 \mathrm{mM}\right.$ PBS buffer $)$, the maximum absorption peak at $550 \mathrm{~nm}$ and the maximum emission peak at $605 \mathrm{~nm}$ were reduced by 
adding $\mathrm{SO}_{3}{ }^{2-} / \mathrm{HSO}_{3}{ }^{-}(750 \mu \mathrm{M})$ to the solution of probe $\mathbf{L}$, and the spectrum was almost unaffected over the $\mathrm{pH}$ range of 3 to 11 .
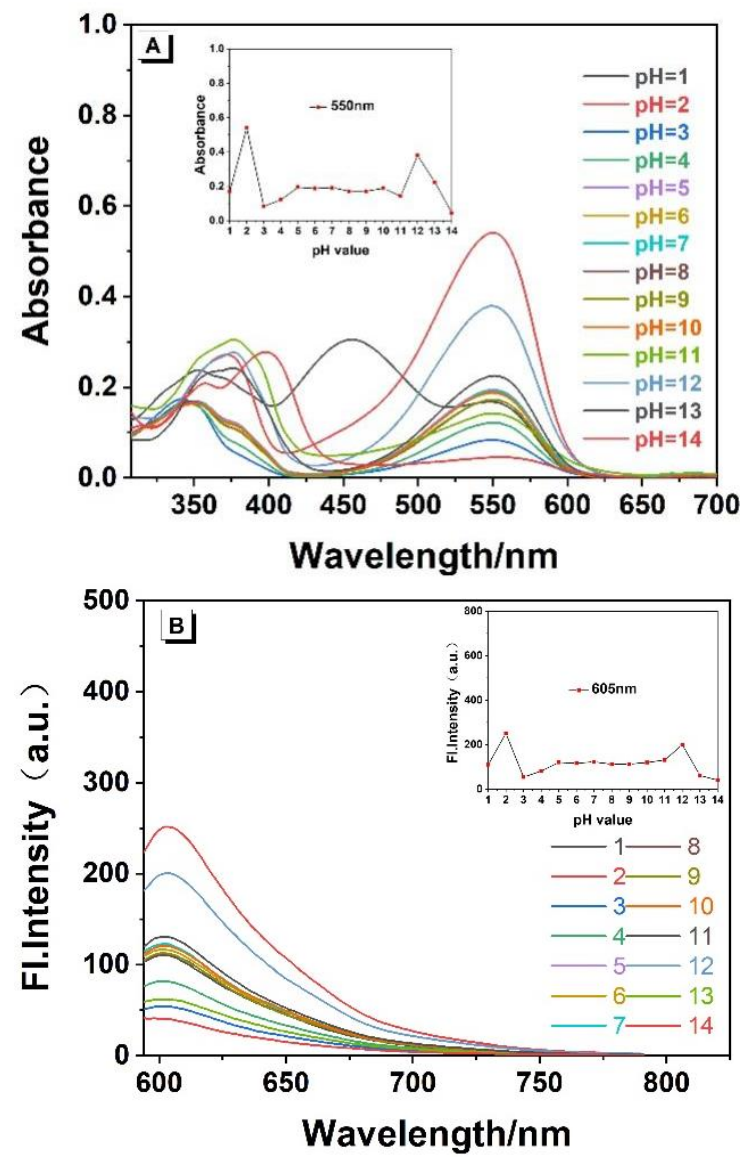

Figure 3. (A) The UV-Vis and (B) fluorescence spectra of the fluorescence probe $\mathbf{L}(15 \mu \mathrm{M})$ in $\mathrm{EtOH} /$ water $\left(\mathrm{V}_{\mathrm{EtOH}} / \mathrm{V}_{\text {water }}=2 / 3\right)$ with the addition of $\mathrm{SO}_{3}{ }^{2-} / \mathrm{HSO}_{3}{ }^{-}(750 \mu \mathrm{M})$ at different $\mathrm{pH}$ values $\left(\lambda_{\mathrm{ex}} / \lambda_{\mathrm{em}}=576 \mathrm{~nm} / 605 \mathrm{~nm}\right.$, slit: $5 / 5 \mathrm{~nm}$, voltage: $\left.600 \mathrm{v}\right)$. Inset: (A) Effect of different $\mathrm{pH}$ values on the absorbance of probe $\mathbf{L}$ with the addition of $\mathrm{SO}_{3}{ }^{2-} / \mathrm{HSO}_{3}{ }^{-}$at $550 \mathrm{~nm}$. (B) Influence of $\mathrm{pH}$ values on fluorescence probe $\mathrm{L}$ with the addition of $\mathrm{SO}_{3}{ }^{2-} / \mathrm{HSO}_{3}{ }^{-}$at $605 \mathrm{~nm}$.

Following the response experiments of water fraction and $\mathrm{pH}$ value to probe $\mathbf{L}$ and the identification and detection of $\mathrm{SO}_{3}{ }^{2-} / \mathrm{HSO}_{3}{ }^{-}$with the probe $\mathbf{L}$, we chose $\mathrm{EtOH} /$ water $\left(\mathrm{V}_{\mathrm{EtOH}} / \mathrm{V}_{\mathrm{H} 2 \mathrm{O}}=2 / 3,10 \mathrm{mM}\right.$ PBS buffer, $\left.\mathrm{pH}=7.40\right)$ as the detection system conditions. We also tested the time-dependent optical stability of probe $\mathbf{L}$ and the $\mathrm{L}_{-} \mathrm{SO}_{3}{ }^{2-} / \mathrm{HSO}_{3}{ }^{-}$ mixture, and the results revealed that $\mathrm{L}$ and the $\mathrm{L}_{-} \mathrm{SO}_{3}{ }^{2-} / \mathrm{HSO}_{3}{ }^{-}$complex responded quickly and were stable over a certain period of time (Figure S4).

\subsection{Anion Sensing Study}

The high selectivity and sensitivity of the probe are key parameters for the detection of domestic water and in vivo studies. Therefore, to test the ability to detect anions, probe $\mathbf{L}(15 \mu \mathrm{M})$ was exposed to many anions (such as $\mathrm{AcO}^{-}, \mathrm{Br}^{-}, \mathrm{C}_{2} \mathrm{O}_{4}{ }^{2-}, \mathrm{ClO}_{4}{ }^{-}, \mathrm{Cl}^{-}, \mathrm{CN}^{-}$, $\mathrm{CO}_{3}{ }^{2-}, \mathrm{F}^{-}, \mathrm{H}_{2} \mathrm{PO}_{4}{ }^{-}, \mathrm{HCO}_{3}{ }^{-}, \mathrm{HSO}_{3}{ }^{-}, \mathrm{HPO}_{4}{ }^{2-}, \mathrm{I}^{-}, \mathrm{NO}^{2-}, \mathrm{PO}_{4}{ }^{3-}, \mathrm{S}_{2} \mathrm{O}_{3}{ }^{2-}, \mathrm{SO}_{3}{ }^{2-}, \mathrm{SO}_{4}{ }^{2-}$, $[\mathrm{A}]^{\mathrm{n}-}=750 \mu \mathrm{M}$ ), metal ions (such as $\mathrm{Ag}^{+}, \mathrm{Al}^{3+}, \mathrm{Cd}^{2+}, \mathrm{Co}^{2+}, \mathrm{Cr}^{3+}, \mathrm{Cu}^{2+}, \mathrm{Fe}^{3+}, \mathrm{Hg}^{2+}, \mathrm{K}^{+}$, $\left.\mathrm{Li}^{+}, \mathrm{Mg}^{2+}, \mathrm{Na}^{+}, \mathrm{Ni}^{2+}, \mathrm{Pb}^{2+}, \mathrm{Zn}^{2+},[\mathrm{M}]^{\mathrm{n}+}=750 \mu \mathrm{M}\right)$ and small amino-containing molecules (such as GSH, Hcy, $\mathrm{H}_{2} \mathrm{NCONH}_{2}, \mathrm{Cys},[\mathrm{M}]^{\mathrm{n}+}=750 \mu \mathrm{M}$ ) in mixtures of $\mathrm{EtOH}$ and water $\left(\mathrm{V}_{\mathrm{EtOH}} / \mathrm{V}_{\mathrm{H} 2 \mathrm{O}}=2 / 3, \mathrm{pH}=7.40\right)$.

As shown in Figure 4, on adding the anions and small amino-containing molecules to the solvent containing $\mathrm{L}$, only $\mathrm{SO}_{3}{ }^{2-} / \mathrm{HSO}_{3}{ }^{-}$caused the solution's color to change via naked-eye observation (Figure S3). The absorption spectra and fluorescence spectra of the 
L-anion mixture indicated that probe $\mathrm{L}$ exhibits good selectivity toward $\mathrm{SO}_{3}{ }^{2-} / \mathrm{HSO}_{3}{ }^{-}$, while other cations or anions (Figure S4) had little impact on the optical behavior of probe L. On other hand, under a $365 \mathrm{~nm}$ UV lamp, only the $\mathrm{L}_{-} \mathrm{SO}_{3}{ }^{2-} / \mathrm{HSO}_{3}{ }^{-}$mixture led to the emission light quenching dramatically (Figure S3). Furthermore, competitive experiments were also performed to investigate the selectivity of the probe toward $\mathrm{SO}_{3}{ }^{2-} / \mathrm{HSO}_{3}{ }^{-}$. When $\mathrm{SO}_{3}{ }^{2-} / \mathrm{HSO}_{3}{ }^{-}$was present in the solution, the absorbance of the mixture decreased at $550 \mathrm{~nm}$, and the emission of the mixture at $\lambda_{\mathrm{em}}=605 \mathrm{~nm}$ was quenched, while without $\mathrm{SO}_{3}{ }^{2-} / \mathrm{HSO}_{3}{ }^{-}$, the absorbance and emission barely changed (Figures 5 and 6 ), which suggested that the coexisting cations/anions/small amino-containing molecules had only a limited impact on the detection of $\mathrm{SO}_{3}{ }^{2-} / \mathrm{HSO}_{3}{ }^{-}$. Thus, the interference experiments indicated that the probe displays high specificity and selectivity for detecting $\mathrm{SO}_{3}{ }^{2-} / \mathrm{HSO}_{3}{ }^{-}$ions.
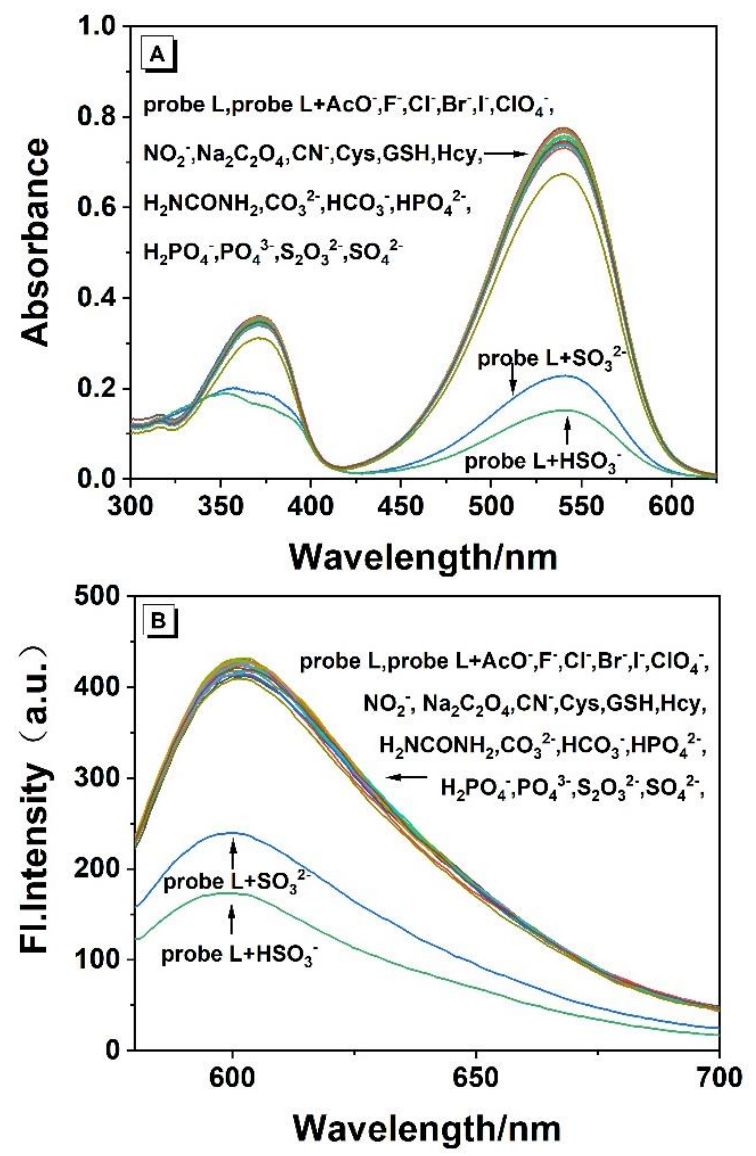

Figure 4. (A) The UV-Vis and (B) fluorescence spectra of the fluorescence probe $\mathbf{L}$ interacting with different anions and small amino-containing molecules $\left(\lambda_{\mathrm{ex}} / \lambda_{\mathrm{em}}=576 / 605 \mathrm{~nm}\right.$, slit: 5/5 nm, voltage: $600 \mathrm{v}$ ).

\subsection{Titration and Detection Limits}

Based on the above experimental conditions, the UV titration experiments were performed with progressive addition of $\mathrm{SO}_{3}{ }^{2-} / \mathrm{HSO}_{3}{ }^{-}$, and the results are presented in Figure 7. As the figure demonstrates, the absorbance of probe $\mathbf{L}$ at $550 \mathrm{~nm}$ gradually decreased as the $\mathrm{SO}_{3}{ }^{2-} / \mathrm{HSO}_{3}{ }^{-}$ions were added. In addition, when the concentration of probe $\mathbf{L}$ changes from 30 to $300 \mu \mathrm{M}$, there exists a good linear relationship between the probe and the $\mathrm{SO}_{3}{ }^{2-} / \mathrm{HSO}_{3}{ }^{-}\left(\mathrm{y}=0.88828-0.02592 \mathrm{x}, \mathrm{R}^{2}=0.99004\right)$. Herein, the detection limit was calculated by utilizing the data of the UV titration experiments following the IUPAC method: 10 groups of blank samples were tested in the absence of sulfite/bisulfite under the same conditions, and then the standard deviation (SD) was calculated from the absorption peak at $550 \mathrm{~nm}$. After that, following the formula: the detection limit $=3 \mathrm{SD} / \mathrm{S}$, 
where $\mathrm{S}$ is the slope of the linear relationship during the UV titration, the detection limit of probe $\mathbf{L}$ for $\mathrm{SO}_{3}{ }^{2-} / \mathrm{HSO}_{3}{ }^{-}$is calculated to be $0.24 \mu \mathrm{M}$. Compared with other $\mathrm{SO}_{3}{ }^{2-} / \mathrm{HSO}_{3}{ }^{-}$ probes (Table $\mathbf{S} 4$ ), the probe $\mathbf{L}$ has the advantages of a lower detection limit and quicker response time.


Figure 5. Bar diagram of the competitive experiments of various anions and small amino-containing molecules on the absorbance (A) and fluorescence intensity (B) of the probe $/ \mathrm{SO}_{3}{ }^{2-} / \mathrm{HSO}_{3}{ }^{-}$complex in buffer solution.

As shown in Figure 8, based on the above experimental conditions, the fluorescence titration experiments were performed with progressive addition of $\mathrm{SO}_{3}{ }^{2-} / \mathrm{HSO}_{3}{ }^{-}$. As the figure demonstrates, the fluorescence intensity of probe $\mathrm{L}$ at $\lambda_{\max \text { em }}=605 \mathrm{~nm}$ gradually decreased as the $\mathrm{SO}_{3}{ }^{2-} / \mathrm{HSO}_{3}{ }^{-}$ions were added. In addition, when the concentration of probe $\mathbf{L}$ changed from 15 to $300 \mu \mathrm{M}$, there exists a good linear relationship between the probe and the $\mathrm{SO}_{3}{ }^{2-} / \mathrm{HSO}_{3}{ }^{-}$ions $\left(\mathrm{y}=350.73493-7.35342 \mathrm{x}, \mathrm{R}^{2}=0.99601\right)$. Herein, the detection limit was calculated by utilizing the data of the fluorescence titration experiments following the IUPAC method: 10 groups of blank samples were tested in the absence of sulfite/bisulfite under the same conditions, and then the standard deviation (SD) was calculated from the emission peak at $605 \mathrm{~nm}$. After that, following the formula: the detection limit $=3 \mathrm{SD} / \mathrm{S}$, where $\mathrm{S}$ is the slope of the linear relationship during the fluorescence titration, the detection limit of probe $\mathrm{L}$ for $\mathrm{SO}_{3}{ }^{2-} / \mathrm{HSO}_{3}{ }^{-}$is calculated to be $9.93 \mathrm{nM}$. Compared with other $\mathrm{SO}_{3}{ }^{2-} / \mathrm{HSO}_{3}{ }^{-}$probes (Table S4), the probe $\mathbf{L}$ has the advantages of a lower detection limit and a simpler synthetic route. 


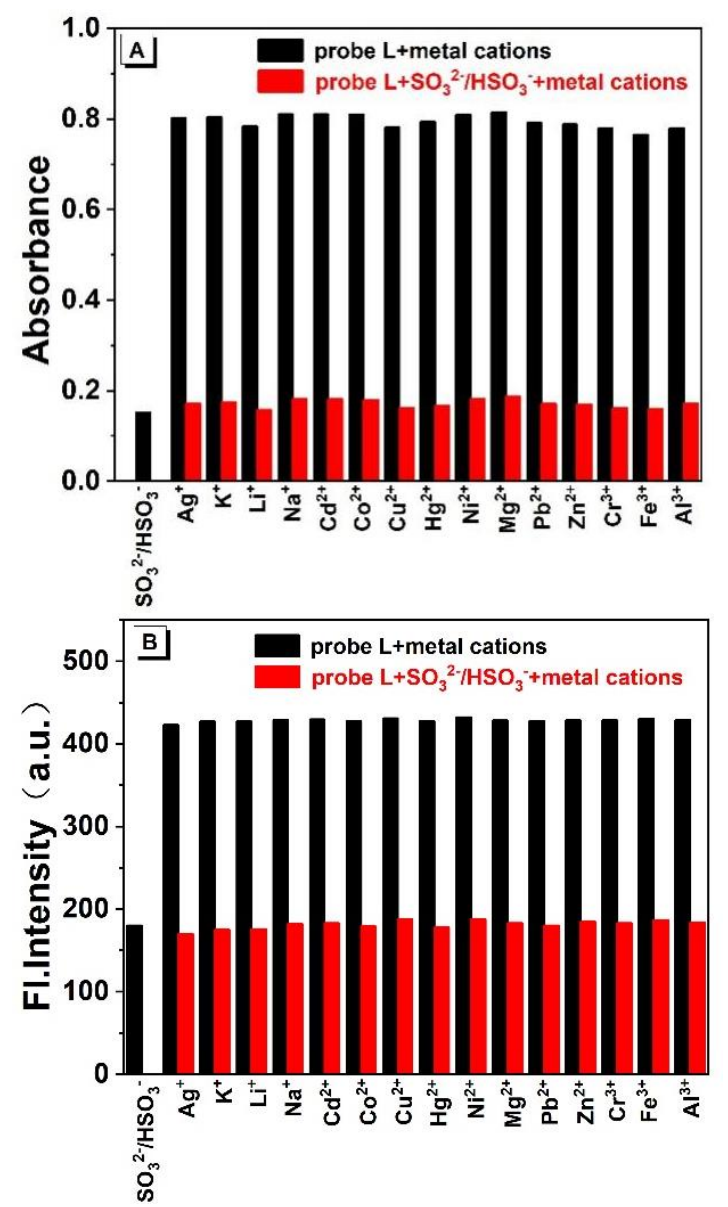

Figure 6. Bar diagram of the competitive experiments of various metal cations on the absorbance (A) and fluorescence intensity $(\mathrm{B})$ of the probe $/ \mathrm{SO}_{3}{ }^{2-} / \mathrm{HSO}_{3}{ }^{-}$complex in buffer solution.

\subsection{A Possible Mechanism for Detection $\mathrm{SO}_{3}{ }^{2-} / \mathrm{HSO}_{3}{ }^{-}$}

The crystal structure shows that the aldehyde group at the 2 position of the 1-hydroxy2,4-diformylnaphthalene reacts with 1,3,3-trimethyl-2-imethylindoline, but the aldehyde group at the 4 position does not react. The result is the fluorescent probe $\mathbf{L}$ in which an electron donor (tertiary amine) and acceptor (carbonyl) are connected by a double bond. The indole ring and the naphthalene ring are not in the same plane, and the dihedral angle between them is $164.95^{\circ}$. The bond length of C24-O2 is only $0.1234 \mathrm{~nm}$, indicating that the phenolic hydroxyl group on the naphthalene ring has changed into the ketone structure (as shown in Figure 9).

According to literature reports on the recognition mechanism of $\mathrm{SO}_{3}{ }^{2-} / \mathrm{HSO}_{3}{ }^{-}$with fluorescent probes [26-28], combined with the above experimental results, it is speculated that the reaction process of probe $\mathbf{L}$ to recognize $\mathrm{SO}_{3}{ }^{2-} / \mathrm{HSO}_{3}{ }^{-}$is as shown in Figure 10 .

Due to the influence of two strongly electron-withdrawing carbonyl groups in the probe structure, the electron cloud density of the $\mathrm{C}=\mathrm{C}$ that connects 1-hydroxy-2,4-diformylnaphthalene and 1,3,3-trimethyl-2-methyleneindoline is not uniform, so it is vulnerable to attack by $\mathrm{SO}_{3}{ }^{2-} / \mathrm{HSO}_{3}{ }^{-}$and the addition reaction of $\mathrm{C}=\mathrm{C}$ occurs, which destroys the original large conjugated structure. With the gradual addition of $\mathrm{SO}_{3}{ }^{2-} / \mathrm{HSO}_{3}{ }^{-}$, the maximum absorption peak of the UV-Vis absorption spectrum and the strongest fluorescence emission peak of the probe gradually decreased, and the color of the solution gradually became lighter. As shown in Figure 11, the reaction solution of probe $\mathbf{L}$ and $\mathrm{NaHSO}_{3}$ was verified by high resolution mass spectrometry. $\left[\mathrm{C}_{24} \mathrm{H}_{24} \mathrm{NO}_{5} \mathrm{~S}\right]^{-}$: the theoretical value was 437.1302 , and the measured value was 437.1262 . 

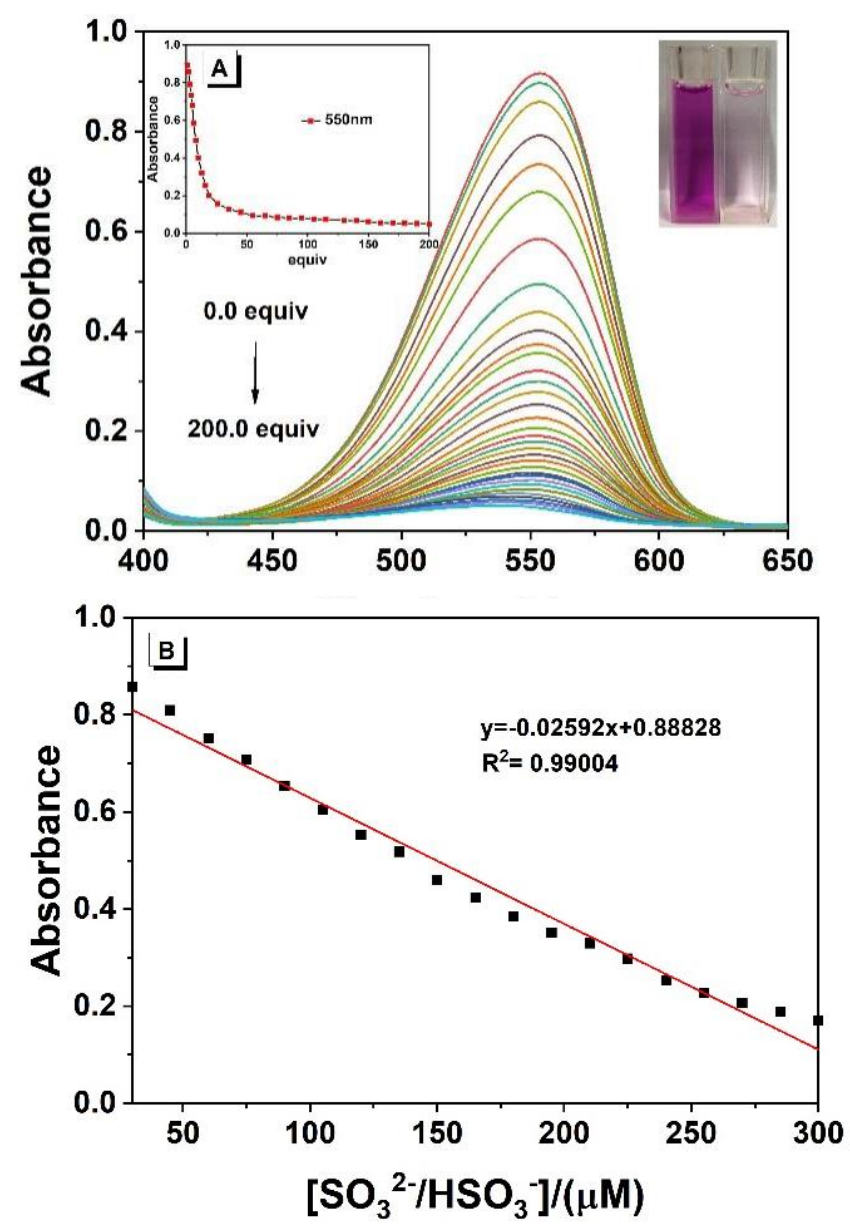

Figure 7. (A) UV-Vis absorption spectra on the addition of $\mathrm{SO}_{3}{ }^{2-} / \mathrm{HSO}_{3}{ }^{-}$to the probe; (B) linear curve of absorbance of probe solution at $550 \mathrm{~nm}$ and concentration of $\mathrm{SO}_{3}{ }^{2-} / \mathrm{HSO}_{3}{ }^{-}(30 \mu \mathrm{M}-300 \mu \mathrm{M})$. Inset: Curve of absorbance at $550 \mathrm{~nm}$ with different concentrations of $\mathrm{SO}_{3}{ }^{2-} / \mathrm{HSO}_{3}{ }^{-}$; photograph of the solutions under illumination with sunlight showing the change in the solution after the titration is complete.

\subsection{Applications}

In order to further evaluate the potential application of probe $\mathbf{L}$ for the detection of $\mathrm{SO}_{3}{ }^{2-} / \mathrm{HSO}_{3}{ }^{-}$in real specimens, water samples from an artificial lake (at Guizhou Medical University) and running water (at our laboratory) have been collected for testing. The specific experimental process is as follows: $3.90 \mathrm{~mL}$ EtOH solution, $100 \mu \mathrm{L}$ probe stock solution $(15 \mu \mathrm{M}), 3 \mathrm{~mL}$ PBS buffer solution and $3 \mathrm{~mL}$ water sample (filtered) were added into one volumetric flask and the mixture was shaken well. At the same time, another water sample was processed with the same steps and an appropriate amount of the standard substance $\left(\mathrm{NaHSO}_{3}\right)$ was added. After standing for $2 \mathrm{~min}$., the absorbance at $550 \mathrm{~nm}$ and fluorescence intensity at $605 \mathrm{~nm}$ of the sample was recorded for further calculations. As shown in Table 1, by UV-Vis absorption spectroscopy, the recoveries of the probe were calculated in the range of $99.20-104.30 \%$ in lake water and $100.01 \sim 104.80 \%$ in tap water. As shown in Table 2, by fluorescence spectroscopy, the recoveries of the probe were calculated in the range of $100.50-108.61 \%$ in lake water and $102.72 \%$ 103.80\% in tap water. These results suggest that $\mathrm{L}$ is a sensitive and selective probe for $\mathrm{SO}_{3}{ }^{2-} / \mathrm{HSO}_{3}{ }^{-}$monitoring in environmental water samples. 

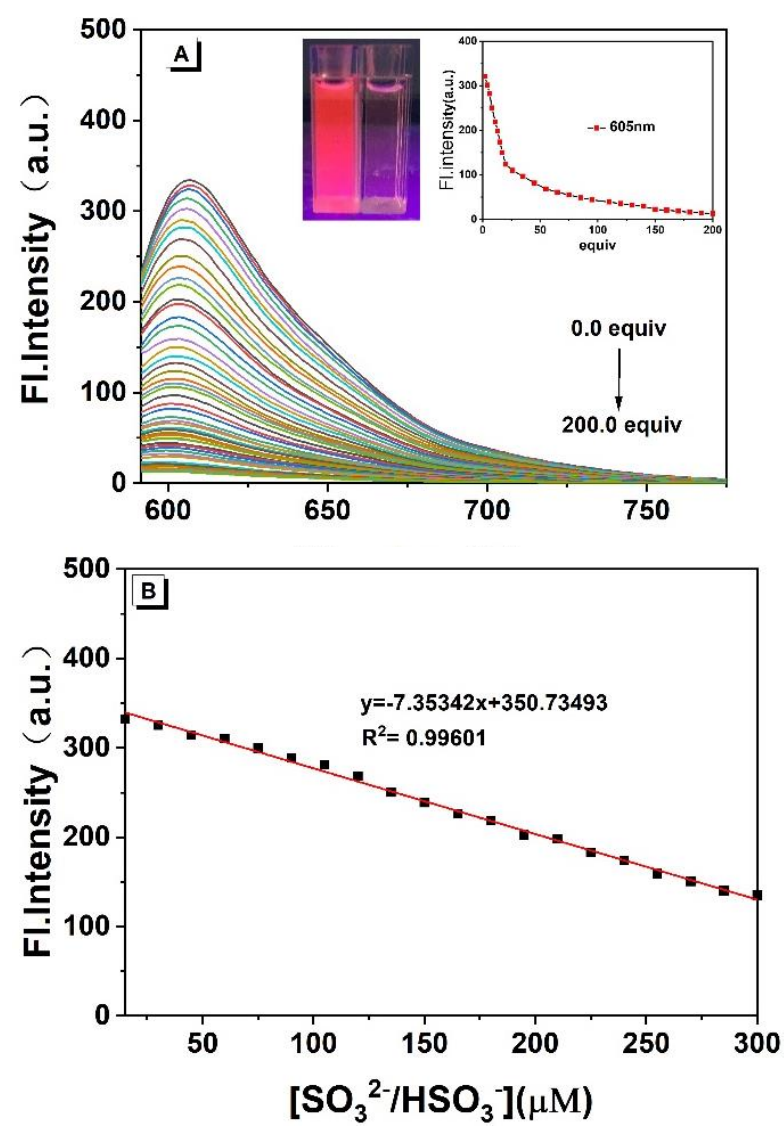

Figure 8. (A) Fluorescence spectra on addition of $\mathrm{SO}_{3}{ }^{2-} / \mathrm{HSO}_{3}{ }^{-}$to the probe; (B) linear curve of fluorescence intensity of probe solution at $\lambda_{\max \text { em }}=605 \mathrm{~nm}$ and concentration of $\mathrm{SO}_{3}{ }^{2-} / \mathrm{HSO}_{3}{ }^{-}$ $(15 \mu \mathrm{M}-300 \mu \mathrm{M})$. Inset: Curve of fluorescence intensity at $\lambda_{\max } \mathrm{em}=605 \mathrm{~nm}$ with different concentrations of $\mathrm{SO}_{3}{ }^{2-} / \mathrm{HSO}_{3}{ }^{-}$; photograph of the fluorescence change under the irradiation of $365 \mathrm{~nm} \mathrm{UV}$ lamp after the titration is complete.



Figure 9. The single crystal X-ray diffraction image of probe $\mathbf{L}$.
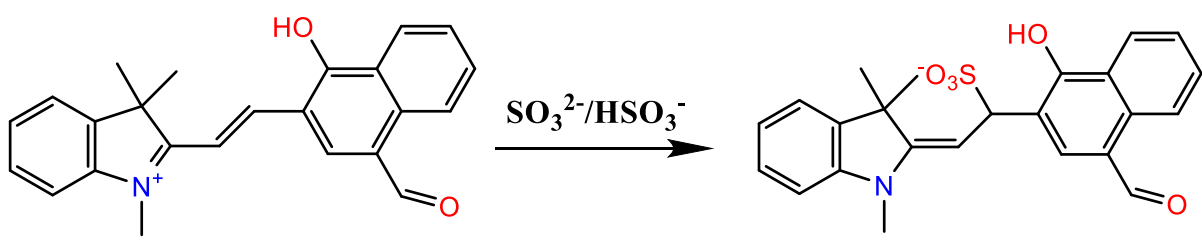

L

Figure 10. Proposed sensing mechanism of probe $\mathbf{L}$ for $\mathrm{SO}_{3}{ }^{2-} / \mathrm{HSO}_{3}{ }^{-}$. 


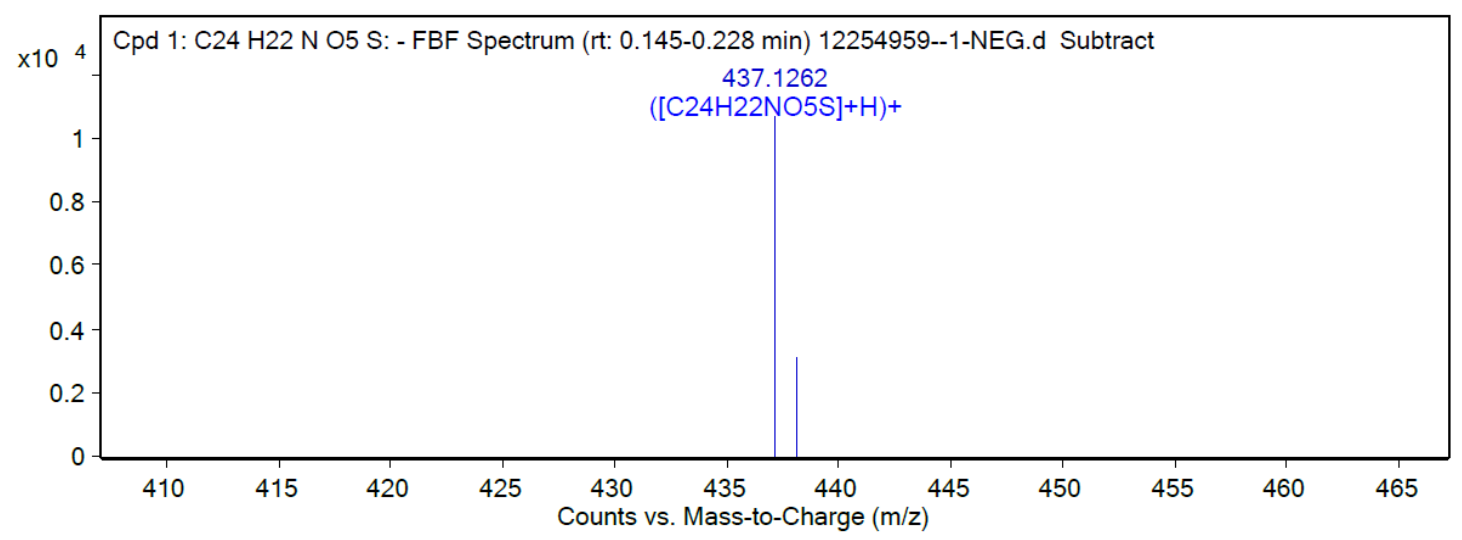

Figure 11. High resolution mass spectra (HRMS) of the reaction product of probe $\mathbf{L}$ upon the addition of $\mathrm{SO}_{3}{ }^{2-} / \mathrm{HSO}_{3}{ }^{-}$.

Table 1. The detail data for $\mathrm{SO}_{3}{ }^{2-} / \mathrm{HSO}_{3}{ }^{-}$detection in real water samples.

\begin{tabular}{|c|c|c|c|c|c|}
\hline Sample & $\begin{array}{l}\text { Measured } \\
\left(\mu \mathrm{mol} \cdot \mathrm{L}^{-1}\right)\end{array}$ & $\begin{array}{c}\text { Added } \\
\left(\mu \mathrm{mol} \cdot \mathrm{L}^{-1}\right)\end{array}$ & $\begin{array}{c}\text { Detected } \\
\left(\mu \mathrm{mol} \cdot \mathrm{L}^{-1}\right)\end{array}$ & $\begin{array}{l}\text { Recovery } \\
(\mathrm{n}=3, \%)\end{array}$ & $\begin{array}{c}\text { RSD } \\
(n=3, \%)\end{array}$ \\
\hline \multirow[t]{3}{*}{ Running water } & 14.23 & 15.00 & 30.63 & 104.80 & 0.70 \\
\hline & & 75.00 & 89.29 & 100.01 & 2.50 \\
\hline & & 150.00 & 166.03 & 101.10 & 3.10 \\
\hline \multirow[t]{3}{*}{ Artificial lake } & 11.06 & 15.00 & 27.11 & 104.00 & 0.90 \\
\hline & & 75.00 & 85.39 & 99.20 & 1.20 \\
\hline & & 150.00 & 168.04 & 104.30 & 2.40 \\
\hline
\end{tabular}

Table 2. The detail data for $\mathrm{SO}_{3}{ }^{2-} / \mathrm{HSO}_{3}{ }^{-}$detection in real water samples.

\begin{tabular}{cccccc}
\hline Sample & $\begin{array}{c}\text { Measured } \\
\left(\mu \mathbf{m o l} \cdot \mathbf{L}^{-\mathbf{1}}\right)\end{array}$ & $\begin{array}{c}\text { Added } \\
\left(\mu \mathbf{m o l} \cdot \mathbf{L}^{-1}\right)\end{array}$ & $\begin{array}{c}\text { Detected } \\
\left(\mu \mathbf{m o l} \cdot \mathbf{L}^{-\mathbf{1})}\right.\end{array}$ & $\begin{array}{c}\text { Recovery } \\
(\mathbf{n = 3 , \% )}\end{array}$ & $\begin{array}{c}\text { RSD } \\
(\mathbf{n}=\mathbf{3}, \mathbf{\%})\end{array}$ \\
\hline Running water & 14.72 & 15.00 & 30.70 & 103.31 & 0.61 \\
& & 75.00 & 93.11 & 103.80 & 3.50 \\
& & 150.00 & 169.20 & 102.72 & 3.01 \\
\hline Artificial lake & 15.92 & 15.00 & 29.64 & 106.20 & 0.52 \\
& & 75.00 & 88.40 & 100.50 & 0.91 \\
\end{tabular}

\section{Conclusions}

In summary, we have developed a new fluorescent probe based on 1-hydroxy-2,4diformylnaphthalene. Furthermore, in the presence of $\mathrm{SO}_{3}{ }^{2-} / \mathrm{HSO}_{3}{ }^{-}$ions, the probe solution showed an obvious color change from pink to colorless under daylight and from bright to dark under UV lamp irradiation with a detection limit as low as $0.24 \mu \mathrm{M}$ using UVVis absorption spectroscopy and $9.93 \mathrm{nM}$ using fluorescence spectroscopy, respectively. This indicates that the probe $\mathrm{L}$ has the potential to be used for the detection of $\mathrm{SO}_{3}{ }^{2-} / \mathrm{HSO}_{3}{ }^{-}$ by the naked eye and via instrumentation. Based on the titration experiments, a good linear relationship was found which allows the probe to be applied to the quantitative and qualitative detection of $\mathrm{SO}_{3}{ }^{2-} / \mathrm{HSO}_{3}{ }^{-}$in real samples. We believe that this work not only provides a new example of a small molecular probe for ion detection, but these results may inform researchers in broader fields such as cell imaging, and such research is ongoing in our laboratory. 
Supplementary Materials: The following are available online, Figure S1: HRMS spectrum of L title, Figure S2: ${ }^{1} \mathrm{H}$ NMR of probe L, Figure S3: ${ }^{13} \mathrm{C}$ NMR of probe L, Figure S4: Uv-vis absorption spectra (A) and fluorescence spectra (B) of probe $\mathbf{L}(15 \mu \mathrm{M})$ in $\mathrm{EtOH} /$ water $\left(\mathrm{V}_{\mathrm{EtOH}} / \mathrm{V}_{\text {water }}=2 / 3, \mathrm{pH}=7.40\right)$ after adding $\mathrm{SO}_{3}{ }^{2-} / \mathrm{HSO}_{3}{ }^{-}(750 \mu \mathrm{M})$ over time $\left(\lambda_{\mathrm{ex}} / \lambda_{\mathrm{em}}=576 / 605 \mathrm{~nm}\right.$, slit: $5 / 5 \mathrm{~nm}$, voltage: $\left.600 \mathrm{v}\right)$, Figure S5: Photographs of probe $\mathbf{L}$-anion complex in EtOH/water $\left(\mathrm{V}_{\mathrm{EtOH}} / \mathrm{V}_{\text {water }}=2 / 3, \mathrm{pH}=7.40\right)$ solution under (A) natural light and (B) $365 \mathrm{~nm}$ UV lamp, Figure S6: (A) UV-vis and (B) Fluorescence spectra of the fluorescence probe $L$ interacting with different cations $\left(\lambda_{\mathrm{ex}} / \lambda_{\mathrm{em}}=576 / 605 \mathrm{~nm}\right.$, slit: 5/5 nm, voltage: $600 \mathrm{v})$. Photographs of probe L-cation complex in EtOH $/$ water $\left(\mathrm{V}_{\mathrm{EtOH}} / \mathrm{V}_{\text {water }}=2 / 3\right.$, $\mathrm{pH}=7.40$ ) solution under (A) natural light and (B) $365 \mathrm{~nm}$ UV lamp, Table S1: Summary of crystal data of probe $\mathbf{L}$, Table S2: The absorbance of probe $\mathbf{L}$ and $\mathrm{L}_{-} \mathrm{SO}_{3}{ }^{2-} / \mathrm{HSO}_{3}{ }^{-}$complex versus different $\mathrm{pH}$ value within $1440 \mathrm{~min}(550 \mathrm{~nm})$, Table S3: The fluorescence intensity (a.u.) of probe $\mathbf{L}$ and ${\mathrm{L}-\mathrm{SO}_{3}}^{2-} / \mathrm{HSO}_{3}{ }^{-}$complex versus different $\mathrm{pH}$ value within $1440 \mathrm{~min}(605 \mathrm{~nm}$, slit: 5/5 nm, voltage: $800 \mathrm{v})$, Table S4: Comparison data with reported $\mathrm{SO}_{3}{ }^{2-} / \mathrm{HSO}_{3}{ }^{-}$sensors.

Author Contributions: Q.S. and L.-Y.S. carried out the experiments, H.X., Z.-Y.W. and Y.-L.H. analyzed the experiment data, L.-Y.S. and X.-J.Y. analyzed the X-ray structure, C.R. and Q.-L.Z. wrote the paper. All authors have read and agreed to the published version of the manuscript.

Funding: This research received no external funding.

Institutional Review Board Statement: Not applicable.

Informed Consent Statement: Not applicable.

Data Availability Statement: No new data were created or analyzed in this study. Data sharing is not applicable to this article.

Acknowledgments: This work was supported by and the National Natural Science Foundation of China $(22065009,22066007)$, the Guizhou Provincial Natural Science Foundation (grant number [2019] 2792, grant number 19NSP042). CR thanks the EPSRC for an Overseas Travel Grant (EP/R023816/1).

Conflicts of Interest: The authors declare no conflict of interest.

Sample Availability: Samples of the compounds L((E)-2-(2-(4-formyl-1-hydroxynaphthalen-2-yl)vinyl)1,3,3-trimethyl-3H-indol-1-ium) are available from the authors.

\section{References}

1. Li, J. Study on Separation of Anions by Capillary Electrophoresis and Its Application in Food Analysis; Zhejiang Gongshang University: Hangzhou, China, 2012.

2. Dong, Y.Q.; Lam, J.W.Y.; Qin, A.; Zhen, L.; Liu, J.; Sun, J.; Dong, Y.; Tang, B.Z. Endowing hexaphenylsilole with chemical sensory and biological probing properties by attaching amino pendants to the silolyl core. Chem. Phys. Lett. 2007, 446, 124-127. [CrossRef]

3. Wang, M.; Zhang, D.Q.; Zhang, G.X.; Tang, Y.L.; Wang, S.; Zhu, D.B. Fluorescence turn-on detection of DNA and labelfree fluorescence nuclease assay based on the aggregation-induced emission of silole. Anal. Chem. 2008, 80, 6443-6448. [CrossRef] [PubMed]

4. Chen, J.W.; Law, C.C.W.; Lam, J.W.Y.; Dong, Y.; Lo, S.M.F.; Williams, I.D.; Zhu, D.; Tang, B.Z. Synthesis, Light Emission, Nanoaggregation, and Restricted Intramolecular Rotation of 1, 1-Substituted 2, 3, 4, 5-Tetraphenylsiloles. Chem. Mater. 2003, 15, 1535. [CrossRef]

5. Chen, J.W.; Xu, B.; Cao, Y. Large blue shifted photoluminescence spectra of silole crystals relative to the amorphous form. Synth. Met. 2005, 1522, 49. [CrossRef]

6. Chen, J.W.; Xu, B.; Yang, K.X.; Cao, Y.; Sung, H.H.Y.; Williams, I.D.; Tang, B.Z. Photoluminescence Spectral Reliance on Aggregation Order of 1, 1-Bis(2'-thienyl)-2,3,4,5-tetraphenylsilole. J. Phys. Chem. B 2005, 109, 17086. [CrossRef]

7. Yang, S.R.; Dong, X.Y. Biological characteristics and research progress of endogenous sulfur dioxide. Mod. Med. J. China 2013, $15,105$.

8. Mi, B.X.; Dong, Y.Q.; Li, Z.; Lam, J.W.Y.; Häußler, M.; Sung, H.H.Y.; Kwok, H.S.; Dong, Y.P.; Williams, I.D.; Liu, Y.Q.; et al. Making silole photovoltaically active by attaching carbazolyl donor groups to the silolyl acceptor core. Chem. Commun. 2005, 3583. [CrossRef]

9. Liu, Y.; Li, K.; Xie, K.-X.; Li, L.-L.; Yu, K.-K.; Wang, X.; Yu, X.-Q. A water-soluble and fast-response mitochondria-targeted fluorescent probe for colorimetric and ratiometric sensing of endogenously generated $\mathrm{SO}_{2}$ derivatives in living cells. Chem. Commun. 2016, 52, 3430. [CrossRef]

10. Samanta, S.; Halder, S.; Dey, P.; Manna, U.; Ramesh, A.; Das, G. A ratiometric fluorogenic probe for the real-time detection of $\mathrm{SO}_{3}{ }^{2-}$ in aqueous medium: Application in a cellulose paper-based device and potential to sense $\mathrm{SO}_{3}{ }^{2-}$ in mitochondria. Analyst 2018, 143, 250-257. [CrossRef] 
11. Ren, Y.; Dong, Y.Q.; Lam, J.W.Y.; Tang, B.Z.; Wong, K.S. Studies on the aggregation-induced emission of silole film and crystal by time-resolved fluorescence technique. Chem. Phys. Lett. 2005, 402, 468. [CrossRef]

12. Zhang, D.; Tang, J.; Cao, C.; Ma, Z.; Wang, Y.; Ma, Y.; Wang, H.; Yin, H.; Liu, J.; Jia, B. New phenanthroimidazole-based fluorescent probe for bisulfite and its application in living cell imaging. J. Lumin. 2019, 205, 299. [CrossRef]

13. Zheng, X.; Li, H.; Feng, W.; Xia, H.-C.; Song, Q.-H. Two-Step Sensing, Colorimetric and Ratiometric Fluorescent Probe for Rapid Detection of Bisulfite in Aqueous Solutions and in Living Cells. ACS Omega 2018, 3, 11831-11837. [CrossRef]

14. Jiang, X.; Xu, J.; Zhang, Y.; Wang, H.; Zeng, L.; Zhang, Y. A colorimetric and ratiometric fluorescent probe for the rapid and sensitive detection of sulfite in sugar. Anal. Methods 2016, 8, 1572. [CrossRef]

15. Zhu, Y.; Du, W.; Zhang, M.; Xu, Y.; Song, L.; Zhang, Q.; Tian, X.; Zhou, H.; Wu, J.; Tian, Y. A series of water-soluble A- $\pi-A^{\prime}$ typological indolium derivatives with two-photon properties for rapidly detecting $\mathrm{HSO}_{3}{ }^{-} / \mathrm{SO}_{3}{ }^{2-}$ in living cells. J. Mater. Chem. B 2017, 5, 3862. [CrossRef]

16. Chen, W.; Fang, Q.; Yang, D.; Zhang, H.; Song, X.; Foley, J. Selective, Highly Sensitive Fluorescent Probe for the Detection of Sulfur Dioxide Derivatives in Aqueous and Biological Environments. Anal. Chem. 2015, 87, 609. [CrossRef]

17. Zhang, X.Q.; Chi, Z.G.; Xu, B.J.; Li, H.Y.; Yang, Z.Y.; Li, X.F.; Liu, S.W.; Zhang, Y.; Xu, J.R. Synthesis of blue light emitting bis(triphenylethylene) derivatives: A case of aggregation-induced emission enhancement. Dyes Pigment. 2011, 89, 56-62. [CrossRef]

18. Chi, Z.G.; Zhang, X.Q.; Xu, B.J.; Zhou, X.; Ma, C.P.; Zhang, Y.; Liu, S.W.; Xu, J.R. Recent advances in organic mechanofluorochromic materials. Chem. Soc. Rev. 2012, 41, 3878-3896. [CrossRef]

19. Liu, L.; Zhang, G.X.; Xiang, J.F.; Zhang, D.Q.; Zhu, D.B. Fluorescence “Turn On" Chemosensors for $\mathrm{Ag}^{+}$and $\mathrm{Hg}^{2+} \mathrm{Based}$ on Tetraphenylethylene Motif Featuring Adenine and Thymine Moieties. Org. Lett. 2008, 10, 4581. [CrossRef]

20. Hong, Y.N.; Chen, S.J.; Leung, C.W.T.; Lam, J.W.Y.; Liu, J.Z.; Tseng, N.W.; Kwok, R.T.K.; Yu, Y.; Wang, Z.K.; Tang, B.Z. Fluorogenic $\mathrm{Zn}(\mathrm{II})$ and Chromogenic Fe(II) Sensors Based on Terpyridine-Substituted Tetraphenylethenes with Aggregation-Induced Emission Characteristics. ACS Appl. Mater. Interface 2011, 3, 3411. [CrossRef]

21. Krause, L.; Herbst-Irmer, R.; Sheldrick, G.M.; Stalke, D. Comparison of silver and molybdenum microfocus X-ray sources for single-crystal structure determination. J. Appl. Crystallogr. 2015, 48, 3-10. [CrossRef]

22. Sheldrick, G.M. SHELXT-Integrated space-group and crystal-structure determination. Acta Crystallograph. Sect. A Found. Adv. 2015, 71, 3-8. [CrossRef]

23. Chan, J.; Dodani, S.C.; Chang, C.J. Reaction-based small-molecule fluorescent probes for chemoselective bioimaging. Nat. Chem. 2012, 4, 973-984. [CrossRef]

24. Lee, M.H.; Kim, J.S.; Sessler, J.L. Small molecule-based ratiometric fluorescence probes for cations, anions, and biomolecules. Chem. Soc. Rev. 2015, 4, 4185-4191. [CrossRef] [PubMed]

25. Feng, X.; Li, Y.; He, X.W.; Liu, H.X.; Zhao, Z.; Kwok, R.T.K.; Elsegood, M.R.J.; Lam, J.W.Y.; Tang, B.Z. A Substitution-Dependent Light-Up Fluorescence Probe for Selectively Detecting $\mathrm{Fe}^{3+}$ Ions and Its Cell Imaging Application. Adv. Funct. Mater. 2018, 28, 1802833. [CrossRef]

26. Xu, J.C.; Yuan, H.Q.; Zeng, L.T.; Bao, G.M. Recent progress in Michael addition-based fluorescent probes for sulfur dioxide and its derivatives. Chin. Chem. Lett. 2018, 29, 1456-1464. [CrossRef]

27. Li, D.Y.; Li, Z.; Yang, X.B.; Zhang, C.X. Research progress of fluorescence probes for sulfur dioxide derivatives. Sci. China 2018, $48,45$.

28. Feng, X.; Zhang, T.; Liu, J.T.; Miao, Y.J.; Zhao, B.X. A new ratiometic fluorescent probe for rapid, sensitive and selective dectetion of endogenous hydrogen sulfide in mitochondria. Chem. Commun. 2016, 52, 3131. [CrossRef] 